\title{
Assessment of the Distribution and Characteristics of the Oldest Forest Stand from the Romanian's Western Plain
}

\author{
Lucian DINCĂ ${ }^{1 *}$, Iulian BRATU ${ }^{2}$ \\ 1 "Marin Drăcea" National Institute for Research and Development in Forestry, Bucharest Romania, B-dul Eroilor \\ 128, Voluntari, Ilfov 077190, Romania \\ 2 "Lucian Blaga" University of Sibiu, Bd-ul Victoriei 10, 550024, Sibiu, Romania \\ *corresponding author: dinka.lucian@gmail.com
}

Bulletin UASVM series Agriculture 77(2) / 2020

Print ISSN 1843-5246; Electronic ISSN 1843-5386

DOI:10.15835/buasvmcn-agr: 2020.0024

\begin{abstract}
The present study analysed the stand of the main forest formations from West Plain based on their composition, age classes, diameters, heights, and the spatial distribution. The stands' analysis did not limit to the study of the distribution of forest species, but also covers aspects regarding the flora, climate and soil. In short, the study presents both the forest station as well as the forest type. The analysed stands belong to the period 1995-2008, from 121608 ha located in the West Plain. The stands are managed by 13 Forests Districts and contain 151 stand elements older than 120 years.
\end{abstract}

Keywords: old grow forests, soil, forest station, age, structure

\section{INTRODUCTION}

The first attention given to the identification and protection of the most valuable specimens of monumental secular trees, took place about 80 years ago (Giurgiu, 2004). At that time, for the Gold Book of Veterans from our forests it was proposed to make an inventory of old and large trees, curiosities and unusual formations, from the forests owned by the State, privately owned ones as well as in parks (Moldovan, 1934).

Large old trees are biological legacies, representing the biological and ecological continuity of genetic resources and constituting habitats for a variety of organisms (Manning et al., 2009). Despite their recognized multiple values, large old trees are in a global decline (Lindenmayer et al., 2014; Faison, 2014), and the urgent need for developing conservation policies to halt their decline was voiced by some authors (Lindenmayer et al., 2014; Blicharska and Mikusinski, 2014).
Some sources attribute the decline of large old oaks to secondary forest successions because these are sensitive to low light conditions, as well as to direct cuttings (Bergmeier et al., 2010; Hartel et al., 2013; Ollerer, 2014).

The aim of present study was to compile an inventory of the oldest stands from the Western Plain from Romania, highlighting the areas occupied by trees older than 120 years. It was analysed the structure of the arboretums, and was registered biometric characteristics, accessibility, and density of the forest road network as well as zoning with functional categories that offer active conservation for the old trees.

\section{MATERIALS AND METHODS}

The stand's age was determined with every forest management plan (conducted at 10 years interval) and is reported from 5 to 5 years. The age was determined by taking into account the 
year when the regeneration occurred as well as by counting the annual rings from the fresh stumps, in addition to the number of years required to achieve the height of the stem at which the determination is made. Based on these standards, the present paper has started with an inventory of all forests from the West Plain (by extracting them from forest management plans realized during 1995-2008 for 13 forests districts) (Forest management plans, 1995-2008). The forests were then organized in a decreasing hierarchy based on their age. Ages over 170 were taken into account for establishing the 151 stand elements that were studied (by using the Excel program and its functions). For each site and stand were analysed besides general characteristics such as the surface and location, also the average diameter and height, stand structure and consistency, field exposition and slope, altitude, soil types and station types.

\section{RESULTS AND DISCUSSIONS}

The analysis of the existent data has shown that the surface occupied by state forests in the West Plain is of 121608 ha.

The distribution of stands on age categories of 20 years each is presented in Figure 1. A relatively uniform distribution can be observed, except for stands over 100 years that occupy only $5 \%$ of the total surface.

The West Plain hosts 151 stand elements for stands over 170 years. The Southern Carpathians have more and older forests (250 years) (Cântar et al., 2019) as the field is hardly accessible there. On the other hand, all forests from the West Plain are easily accessible so they were cut at their exploitability age.

By refering strictly to the old analysed stands, can be observed that the number of old stands decreases (Figure 2), as it was reported also in the Southern Carpathians (Cântar et al., 2019).

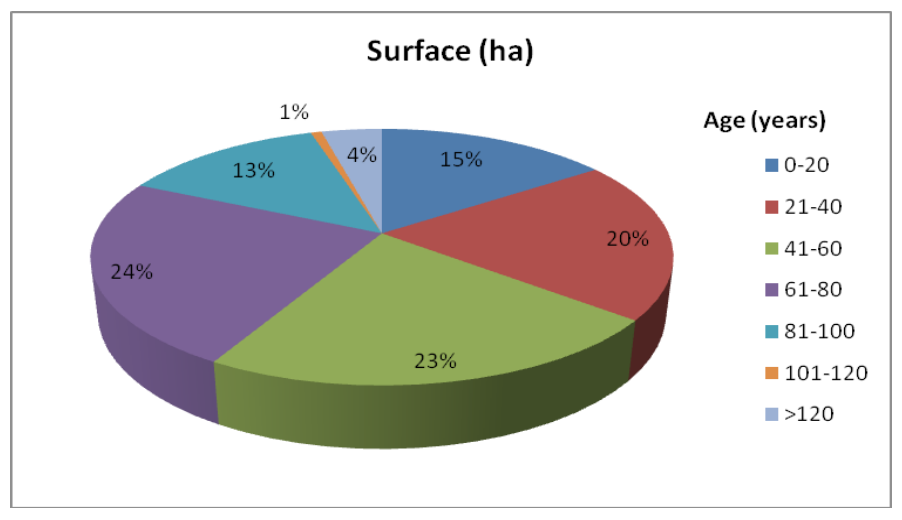

Figure 1. The distribution of stands from the West Plain on age categories

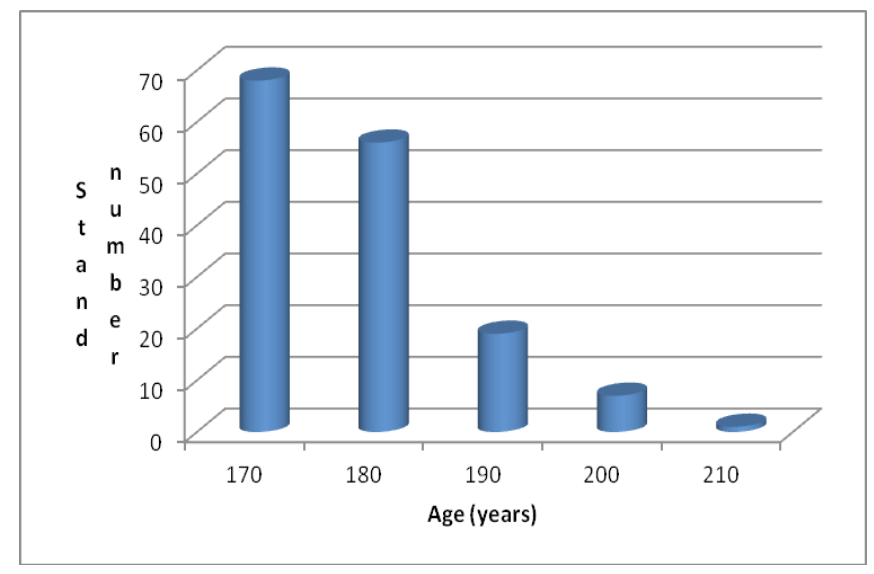

Figure 2. The surface occupied by the oldest stands from the West Plain 
The oldest stand from this area is a 210-yearold common beech stand from Lunca Timișului. This one is followed by 200-year-old stands located also in Lunca Timișului, with the exception of one stand situated in Timișoara Forest Districts. By far, the oldest stands are located in Lunca Timișului (126 stands), followed by Timișoara (39 stands), Lugoj (17 stands) and Săvârșin (5 stands). Old stands are not found at all in the central and north part of the West Plain (Bihor and Satu Mare Counties) (Figure 3).

Table number 1 presents the oldest 27 stands together with their most representative characteristics.

Pedunculate oak (Quercus robur L.) is the characteristic species for the oldest stands located in the West Plain. Ash (Fraxinus excelsior L.) and sessile oak (Quercus petraea (Matt.) Liebl.) are sporadically present.

The average diameter and height of the oldest stands from this area registered high values with average diameters between 60 and $98 \mathrm{~cm}$ and average heights between 26 and $33 \mathrm{~m}$ (Table 1).

The stands structure is relatively heterogeneous regarding the age (stands with different ages that exceed 20 years for seed trees and 5 years for sprout trees). Only a few stands are homogeneousaged (where all trees have the same age and originate from the same fructification or from artificial regeneration or from sprouts and suckers after cuttings). Old stands with a relatively even-aged or uneven-aged structure do not exist in this area.

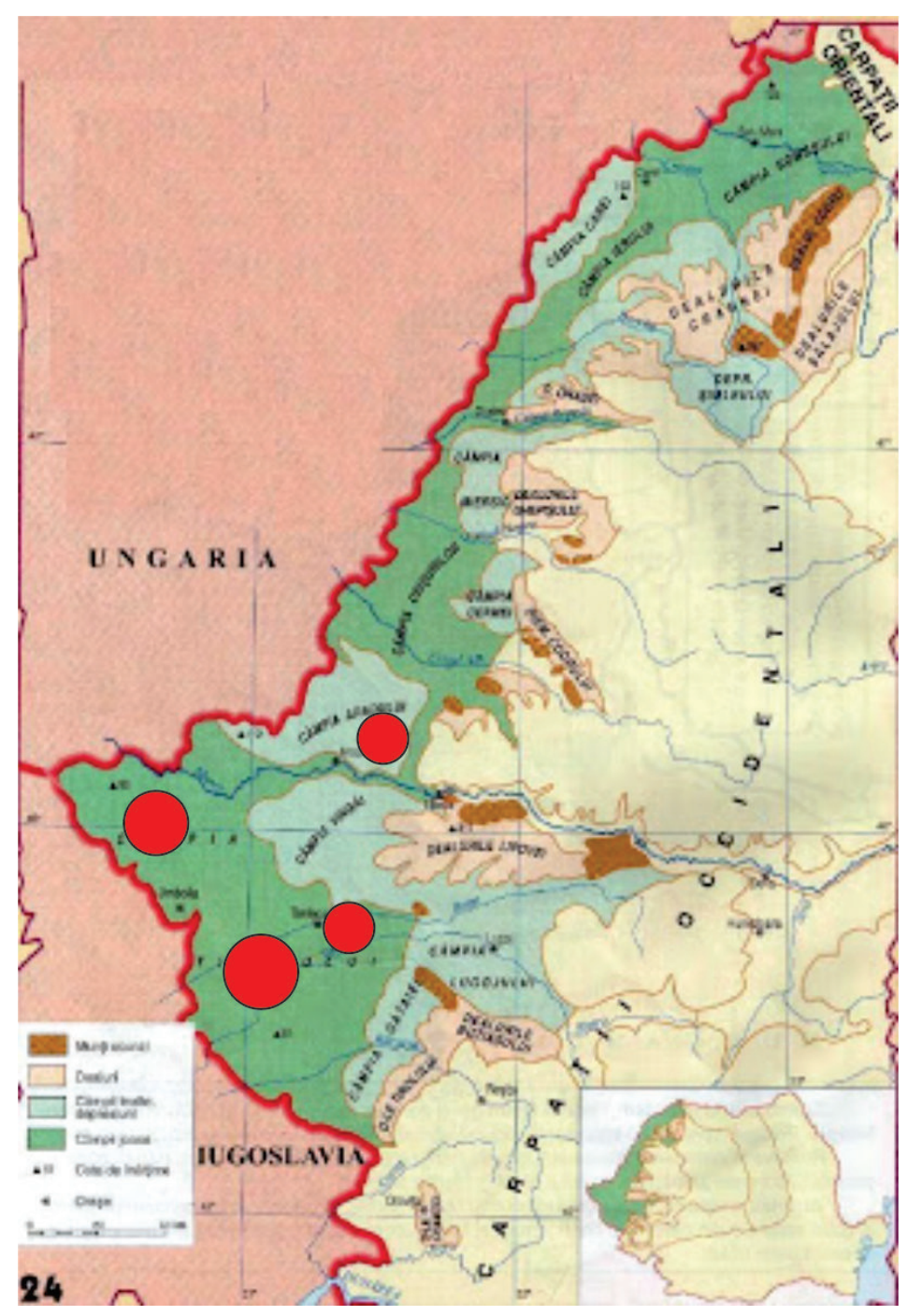

Figure 3. The location of the oldest stands from the West Plain (http://geografiebranesti.blogspot.com - main map) 
Table 1. The oldest 27 stands from the West Plain

\begin{tabular}{|c|c|c|c|c|c|c|c|c|c|c|c|}
\hline $\begin{array}{c}\text { Forest } \\
\text { District }\end{array}$ & Species & $\begin{array}{c}\text { Surface } \\
\text { (ha) }\end{array}$ & $\begin{array}{c}\text { Age } \\
\text { (years) }\end{array}$ & $\begin{array}{l}\text { Average } \\
\text { diameter } \\
\text { (cm) }\end{array}$ & $\begin{array}{c}\text { Average } \\
\text { height } \\
\text { (m) }\end{array}$ & $\begin{array}{l}\text { Struc- } \\
\text { ture }\end{array}$ & $\begin{array}{l}\text { Distance } \\
\text { from the } \\
\text { road }\end{array}$ & $\begin{array}{l}\text { Functional } \\
\text { category }\end{array}$ & Flora & Soil & $\begin{array}{c}\text { Station } \\
\text { type }\end{array}$ \\
\hline $\begin{array}{c}\text { Lunca } \\
\text { Timișului }\end{array}$ & $\begin{array}{l}\text { peduncu- } \\
\text { late oak }\end{array}$ & 6.6 & 210 & 78 & 33 & 3 & 9 & $4 \mathrm{~J}$ & 81 & 2102 & 8512 \\
\hline L. Timiș & p. oak & 1.1 & 200 & 98 & 30 & 3 & 7 & $5 \mathrm{~J}$ & 71 & 2101 & 8511 \\
\hline L. Timiș & p. oak & 1.5 & 200 & 78 & 28 & 3 & 6 & $4 \mathrm{~J}$ & 71 & 2101 & 8511 \\
\hline L. Timiș & p. oak & 0.9 & 200 & 80 & 33 & 1 & 7 & $4 \mathrm{~J}$ & 71 & 2109 & 8511 \\
\hline L. Timiș & p. oak & 0.5 & 200 & 60 & 30 & 3 & 15 & $4 \mathrm{~J}$ & 71 & 2102 & 8512 \\
\hline L. Timiș & p. oak & 0.5 & 200 & 68 & 28 & 3 & 15 & $4 \mathrm{~J}$ & 71 & 2102 & 8512 \\
\hline L. Timiș & p. oak & 1.3 & 200 & 72 & 32 & 3 & 16 & $4 \mathrm{~J}$ & 71 & 2102 & 8512 \\
\hline Timișoara & p. oak & 0.2 & 200 & 86 & 26 & 3 & 13 & $5 \mathrm{C}$ & 73 & 2102 & 9641 \\
\hline L. Timiș & p. oak & 6.6 & 190 & 76 & 31 & 3 & 5 & $4 \mathrm{~B}$ & 71 & 2102 & 8512 \\
\hline L. Timiș & p. oak & 4.5 & 190 & 84 & 32 & 3 & 4 & $4 \mathrm{~B}$ & 71 & 2102 & 8512 \\
\hline L. Timiș & p. oak & 8.4 & 190 & 88 & 24 & 3 & 4 & $4 \mathrm{~B}$ & 71 & 2102 & 8512 \\
\hline L. Timiș & p. oak & 0.6 & 190 & 68 & 32 & 1 & 7 & $4 \mathrm{~J}$ & 71 & 2109 & 8511 \\
\hline L. Timiș & p. oak & 4.4 & 190 & 88 & 31 & 1 & 7 & $4 \mathrm{~J}$ & 71 & 2119 & 8512 \\
\hline L. Timiș & ash & 4.4 & 190 & 68 & 30 & 1 & 7 & $4 \mathrm{~J}$ & 71 & 2119 & 8512 \\
\hline L. Timiș & p. oak & 1.7 & 190 & 74 & 31 & 3 & 11 & $5 \mathrm{~J}$ & 71 & 2102 & 8512 \\
\hline L. Timiș & p. oak & 1.3 & 190 & 66 & 30 & 3 & 9 & $4 \mathrm{~J}$ & 81 & 2102 & 8512 \\
\hline L. Timiș & ash & 1.3 & 190 & 78 & 33 & 3 & 9 & $4 \mathrm{~J}$ & 81 & 2102 & 8512 \\
\hline L. Timiș & p. oak & 1.4 & 190 & 78 & 31 & 3 & 14 & $4 \mathrm{~J}$ & 71 & 2102 & 8512 \\
\hline L. Timiș & p. oak & 1.7 & 190 & 62 & 32 & 3 & 14 & $4 \mathrm{~J}$ & 71 & 2102 & 8512 \\
\hline L. Timiș & p. oak & 2.5 & 190 & 68 & 26 & 3 & 14 & $4 \mathrm{~J}$ & 71 & 2102 & 8512 \\
\hline L. Timiș & ash & 2.5 & 190 & 64 & 32 & 3 & 14 & $4 \mathrm{~J}$ & 71 & 2102 & 8512 \\
\hline L. Timiș & p. oak & 0.6 & 190 & 76 & 31 & 3 & 14 & $4 \mathrm{~J}$ & 71 & 2102 & 8512 \\
\hline L. Timiș & p. oak & 0.5 & 190 & 70 & 26 & 3 & 14 & $4 \mathrm{~J}$ & 71 & 2102 & 8512 \\
\hline L. Timiș & p. oak & 3.8 & 190 & 76 & 32 & 1 & 13 & $4 \mathrm{~J}$ & 71 & 2102 & 8512 \\
\hline L. Timiș & p. oak & 0.1 & 190 & 74 & 30 & 1 & 16 & $4 \mathrm{~J}$ & 71 & 2102 & 8512 \\
\hline L. Timiș & p. oak & 2.0 & 190 & 84 & 26 & 3 & 8 & $3 \mathrm{G}$ & 74 & 2202 & 8332 \\
\hline Lugoj & sessile oak & 0.4 & 190 & 82 & 29 & 3 & 6 & $1 \mathrm{~A}$ & 61 & 2201 & 6151 \\
\hline
\end{tabular}

Note: Terms present in the table represent: Structure: 1= even-aged stand; 3=relatively uneven-aged stand. Functional category: 3G= Dispersed forest bodies, with surfaces of 100 ha, situated in field areas; 1,4B= Forests from around counties, cities and villages, as well as forests situated in their buildable areal; 1,4J= Forests with an exceptional game interest; 1,5C= Natural reservations; 1,5J= Secular forests of exceptional value as well as portions of forests with rare species; $2,1 \mathrm{~A}=$ Forests destined to mainly produce thick trees of superior quality.

Flora: 61= Asarum-Stellaria; 71= Erachypodium-Geum-Pulmonaria; 73=Carex pilosa; 74=Carex brizoides-Agrostis alba; 81= Arum-Pulmonaria. Soil type: 2101= redic preluvisol; 2102= mollic redic preluvisol; 2109= redic verticstagnic preluvisol; 2109= redic vertic preluvisol; 2201= preluvisol ; 2219=vertic-rendzic preluvisol.

Station type: 6151= Hill oak stands (Hungarian oak, Turkish oak) Bi small edaphic eutricambosol; 8511= Forest plain, meadow, Bm high edaphic stagnosol; 8512= Forest plain, meadow, Bs high edaphic stagnosol; 9641= Meadow silvosteppe, Bm, zonal phreatic soil, humid, stagnic and semigleic that is non-flooding or rarely flooded. 
The structure of these stands can become an important criterion for creating smart forests as was recorded in the Southern Carpathians for Norway spruce (Dincă et al., 2019b), or for alder (Blaga et al., 2019).

The distance from the closest road is relatively small (4-9 km) in most cases. However, in numerous cases are recorded higher distances (10-16 km), a fact that is explained by the nature of these stands (old forests that have remained unexploited, either located in protected areas or in inaccessible areas).

The functional category is assigned to each arboretum within the forest management plans by which are given special protection functions (e.g. soil, water, wildlife, etc.), or protection and production (generally wood production). In this study, the functional category of the majority of these stands is 4I (Forests with an extreme game interest), followed by some stands that belong to 4B (Forests from around counties, cities and villages) and 5J (Secular forests of extreme value). Erachypodium-Geum-Pulmonaria is the flora specific for these stands, followed sometimes by Arum-Pulmonaria.

The most commonly found soil types for these stands are mollic redic preluvisol (dominant), redic vertic-stagnic preluvisol and redic vertic preluvisol. All these soils are preluvisol subtypes from the Luvisol class. They are rich in nutritive elements (Crișan et al., 2017; Dincă et al., 2019a), but present a humidity deficit in certain periods of the year (Dincă et al., 2018).

The station types specific for these old stands are Forest meadow plain, Bs high edaphic stagnosol and Forest meadow plain Bm high edaphic stagnosol. The mentioned station types are of high favourability for local stands, a fact that is translated in high tree dimensions and advanced ages as well as by the other ecosystem services that the forest can offer (Spârchez et al., 2011; Enescu et al., 2018; Pleșca et al., 2019; Dincă and Achim, 2019).

\section{CONCLUSIONS}

Pedunculate oak (Quercus robur L.) is amongst the most important deciduous tree species from Europe. In the West Plain, this species forms some of the oldest stands (reaching advanced ages of 210 years). The stands older than 120 years ( $5 \%$ of the total number of studied stands) are represented by pedunculate oak (86\%), ash (13\%) and sessile oak $(1 \%)$. The lack of protected natural areas on extended surfaces as well as the existence of a dense network of roads has led to narrow surfaces where old aged stands can grow. From a functional point of view, the most significant surfaces are occupied by stands with game functions (46\%), by forests from around counties, cities and villages $(32 \%)$ and by secular forests with an exceptional value (5\%). In regard with their structure, the old stands are almost exclusively uneven-aged (77\%).

The dominant soil type belongs to the Luvisol class - mollic redic preluvisol. The station on which old stands grow in the West Plain is favourable and implies remarkable diameters and heights.

We can conclude that the West Plain offers extremely favourable conditions for the growth and development of oak stands. However, the small surface occupied by old stands is caused by the absence of protected natural areas and by the high accessibility degree.

\section{REFERENCES}

1. Bergmeier E, Petermann J, Schroder E (2010). Geobotanical survey of wood-pasture habitats in Europe: Diversity, threats and conservation. Biodiversity and Conservation 19: 2995-3014. Doi: 10.1007/s10531-0109872-3.

2. Blaga T, Dinca L, Pleșca IM (2019). How can smart alder forests (Alnus glutinosa (L.) Gaertn.) from the Southern Carpathians be indentified and managed. Scientific Papers Series Management, Economic Engineering in Agriculture and Rural Development, 19(4): 29-35.

3. Blicharska M, Mikusinski G (2014). Incorporating social and cultural significance of large old trees in conservation policy. Conservation Biology, 28: 1558-1567. Doi: 10.1111/cobi.12341.

4. Cântar IC, Dincă L, Chisăliță I, Crișan V, Kachova V (2019). Identifying the oldest stands from the Southern Carpathians together with their main characteristics. Proceedings of the Multidisciplinary Conference on Sustainable development, Filodiritto International Proceedings, p. 186-193.

5. Crișan V, Dincă L (2017). The predominant forest soils from Timiș Forest Administration County. Journal of Horticulture, Forestry and Biotechnology, 21(3): 137-141.

6. Dinca L, Badea O, Guiman G, Braga C, Crisan V, Greavu V, Murariu G, Georgescu L (2018). Monitoring of soil moisture in Long-Term Ecological Research (LTER) sites of Romanian Carpathians. Annals of Forest Research, 61(2): 171-188. Doi: 10.15287/afr.2018.1188.

7. Dinca L, Chisalita I, Cantar IC (2019a). Chemical properties of forest soils from Romania's West Plain. Revista de Chimie, 70(7): 2371-2374. 
8. Dincă L, Achim F (2019). The management of forests situated on fields susceptible to landslides and erosion from the Southern Carpathians. Scientific papers series Management, Economic Engineering in Agriculture and Rural Development, 19(3): 183-188.

9. Dincă L, Murariu G, Iticescu C, Budeanu M, Murariu A (2019b). Norway spruce (Picea Abies (L.) Karst.) smart forests from Southern Carpathians. International Journal of Conservation Science, 10(4): 781-790.

10. Enescu CM, Dincă L, Cântar I, (2018). Which are the most common non-wood forest products in Timis County? Research Journal of Agricutural Science, 50(1): 51-56.

11. Faison EK (2014). Large old tree declines at broad scales: A more complicated story. Conservation Letters, 7: 70-71. Doi: $10.1111 /$ conl.12075.

12. Giurgiu V (2004). Iuliu Moldovan precursor al silviculturii experimentale românești (1935-1964). Academia Română-ASAS, p. 19.

13. Hartel T, Dorresteijn I, Klein C, Mathe O, Moga CI, Ollerer K, Roellig M, von Wehrden H, Fischer J (2013). Woodpastures in a traditional rural region of Eastern Europe: Characteristics, management and status. Biological Conservation, 166: 267-275.

14. Lindenmayer DB, Banks SC, Laurance WF, Franklin JF, Likens GE (2014). Broad decline of populations of large old trees. Conservation Letters, 7:72-73. Doi:10.1111/ conl.12079.
15. Manning AD, Gibbons P, Lindenmayer DB (2009). Scatteredtrees: A complementary strategy for facilitating adaptiveresponses to climate change in modified landscapes? Journalof Applied Ecology 46: 915919. Doi: 10.1111/j.1365-2664.2009.01657.x.

16. Moldovan I (1934). Monumentele naturale ale pădurilor noastre. Viaţa Forestieră, 12: 634.

17. Ollerer K (2014). The ground vegetation management of wood-pastures in Romania-Insights in the past for conservation management in the future. Applied Ecology and Environmental Research, 12: 549-562.

18. Pleșca IM, Blaga T, Dincă L, Breabăn IG (2019). Prioritizing the potential of non-wood forest products from Arad county by using the analytical hierarchy process. Present Environment and Sustainable Development, 13(2): 225233, Doi: 10.2478/pesd-2019-0038.

19. Spârchez G, Târziu D, Dincă L, Cioc C, Enache R (2011). The characteristics of some Quercus stations and hill mixed hardwood forests (FD2) from the west part of the Getic highland. Proceedings of the Biennial International Symposium, Forest and Sustainable Development, Brașov, Romania, 99-104, Transilvania University Press.

20. *** Forest management plans 1995-2008: Carei (2008), Livada (2001), Satu Mare (2004), Oradea (2007), Săcuieni (2008), Tinca (2004), Ceala (2001), Chișinău Criș (2001), Radna (1995), Săvârșin (2005), Lunca Timișului (2007), Timișoara (2007), Lugoj (1999) 